\title{
Uji Kinerja Mesin EkstraksiTipe Stirrer Rotary Blade Bertenaga Motor Bakar Bensin Untuk Mengekstraksi Pati Singkong
}

\author{
Performance Test of Stirrer Rotary Blade Type of Starch Extraction Machine \\ Powered by Gasoline Enginefor Cassava Starch Extracting
}

\author{
Darma $^{1 *}$, Desi Natalia Edowai ${ }^{2}$, Marinus Kogoya ${ }^{3}$ \\ 1,2Jurusan Teknik Pertanian dan Biosistem, Fakultas Teknologi Pertanian Unipa \\ Jl. Gunung Salju amban, Manokwari 98314. \\ ${ }^{3}$ Jurusan Teknologi Hasil Pertanian, Fakultas Teknologi Pertanian Unipa \\ Jl. Gunung Salju amban, Manokwari 98314. \\ "Email: darmabond@gmail.com
}

\begin{abstract}
Small-scale cassava starch processing in Indonesia, including in West Papua has bright opportunities and development to meet market demand. The demand for cassava starch in Indonesia tends to increase continuously due to the increase of both food and non-food industries which use cassava starch as raw material. Recently, the demand for cassava starch (tapioca flour) nationally, as well as in Manokwari, West Papua, has not yet been met by the supply of existing tapioca processing industries. One of the important stages in cassava starch processing is starch extraction which aims to obtain the maximum amount of starch. The starch extraction process can be conducted either manually, semi mechanically, or fully mechanically. The objective of this research was to test the performance of a stirrer rotary blade type of starch extraction machine powered by a gasoline engine for cassava starch extracting. The performance of the machine was evaluated by measuring the parameters of extraction capacity, wet starch rendement, dry starch rendement, and starch losses in waste. Results showed that the machine worked properly to extract cassava starch. The performance of the machine was (1) extraction capacity $220.3 \mathrm{~kg}$ of rasped tubers/hour, (2) wet starch rendement $46.47 \%$, (3) dry starch rendement $28.88 \%$, and (d) starch losses in waste $2.6 \%$.
\end{abstract}

Keywords: cassava starch, extraction machine, performance test, stirrer rotary blade

\begin{abstract}
Abstrak
Pengolahan pati singkong skala kecil di Indonesia, termasuk di Papua Barat memiliki peluang dan prospek pengembangan yang cerah untuk memenuhi permintaan pasar. Permintaan tapioka di Indonesia cenderung terus meningkat karena terjadi peningkatan jumlah industri pangan maupun nonpangan yang menggunakan pati singkong sebagai bahan baku. Pada saat ini permintaan terhadap pati singkong (tepung tapioka) secara nasional, termasuk di Manokwari Papua Barat belum bisa terpenuhi oleh industri pengolahan tapioka yang ada. Salah satu tahapan penting dalam proses pengolahan pati singkong adalah ekstraksi pati yang bertujuan untuk memisahkan pati sebanyak mungkin dari ampas. Proses ekstraksi pati dapat dilakukan secara manual, semi mekanis dan full mekanis. Penelitian ini bertujuan untuk menguji kinerja mesin ekstraksi pati tipe stirrer rotary blade bertenaga motor bakar bensin untuk ekstraksi pati singkong. Evaluasi kinerja dilakukan dengan mengukur parameter kapasitas ekstraksi, rendemen pati basah, rendemen pati kering dan kehilangan pati pada ampas. Dari hasil pengujian kinerja menunjukan bahwa mesin dapat berfungsi dengan baik untuk mengekstraksi pati singkong. Kinerja mesin adalah (1) kapasitas ekstraksi $220,3 \mathrm{~kg}$ umbi parut/jam, (2) rendemen pati basah $46,47 \%$, (3) rendemen pati kering $28,88 \%$ dan (d) kehilangan pati pada ampas $2,6 \%$.
\end{abstract}

Kata kunci: pati singkong, mesin ekstraksi, uji kinerja, stirrer rotary blade 


\section{PENDAHULUAN}

Singkong/cassava (Manihot esculenta Crantz) merupakan tanaman tropis yang kaya akan karbohidrat. Umbi singkong selain digunakan sebagai sumber pangan pokok, juga digunakan sebagai bahan dasar industri (starch based industries) dan pakan ternak. Tanaman ini telah dikenal luas oleh masyarakat di negara-negara tropis termasuk di Indonesia. Singkong memiliki kemampuan untuk tumbuh dan berproduksi dengan baik pada tanah-tanah tidak subur dengan perawatan seadanya, dan karenanya banyak ditanam oleh petani di seluruh Indonesia termasuk di Papua. Indonesia merupakan negara penghasil singkong nomor 6 di dunia setelah Nigeria, Congo, Ghana, Brazil dan Thailand dengan produksi pada tahun 2016 adalah 20.261.000 ton (FAO, 2018).

Industri pengolahan singkong menjadi pati singkong/cassava starch atau lebih dikenal dengan istilah tepung tapioka memiliki potensi ekonomi tinggi sehingga mendorong lahirnya lebih dari 70 industri tapioka yang ada di Indonesia dengan skala produksi dan tingkatan teknologi yang beragam yaitu mekanik sederhana, semi modern, dan full otomatik yang tersebar di Sumatera, Jawa dan Kalimantan(Kementerian Tenaga Kerja, 2016). ProvinsiPapua Barat dan Papua juga memiliki prospek yang cerah untuk pengembangan industri pengolahan tapioka karena didukung oleh ketersediaan bahan baku berupa singkong yang memadai. Produksi singkong di Provinsi Papua Barat pada tahun 2017 sebesar 10.783 ton, dengan jumlah produksi di Kabupaten Manokwari yaitu 1.773 ton/tahun (BPS Provinsi Papua Barat, 2018). Pada saat ini terdapat $1 \mathrm{UMKM}$ industri pengolahan tepung tapioka yang berlokasi di Kampung Mokwam Distrik Masni SP-5 Prafi.

Industri tepung tapioka merupakan industri yang memiliki peluang dan prospek pengembangan yang baik untuk memenuhi permintaan pasar. Industri tepung tapioka termasuk industri hilir, dimana industri ini melakukan proses pengolahan dari bahan baku singkong menjadi tepung tapioka. Permintaan tapioka di Indonesia cenderung terus meningkat. Peningkatan tersebut karena terjadi peningkatan jumlah industri makanan dan non makanan, industri tekstil, kertas, sorbitol, dan lain sebagainya yang menggunakan tepung tapioka sebagai bahan baku industrinya (Kementerian Tenaga Kerja, 2016).

Proses pengolahan tapioka bertujuan untuk mengekstrak pati yang terkandung dalam umbi singkong. Tahapan proses ekstraksi pati singkong adalah pengupasan kulit, pencucian umbi, pemarutan, ekstraksi pati, pengendapan, pencucian pati (pemutihan), pengeringan, penggilingan dan pengemasan. Setiap tahapan proses saling terkait satu sama lain, sehingga keberhasilan masing-masing tahapan proses akan mempengaruhi keberhasilan proses secara keseluruhan.

Salah satu tahapan penting dalam proses pengolahan tapioka adalah ekstraksi pati yaitupemisahan pati dari komponen lainnya menggunakan saringan dengan bantuan air.Ekstraksi pati singkong dapat dilakukan secara manual atau menggunakan mesin tergantung pada kapasitas produksi yang ingin dicapai.Pada industri-industri pengolahan skala kecil, menengah dan besar, ada 2 tipe mesin ekstraksi pati singkong yang umum digunakan yaitu (1) saringan berayun (shaking screen) dan saringan berputar (rotating screen) (Guillaume et al., 2008; Rajakumari, 2010). Pengolahan tapioka di Industri Kecil menengah (IKM) Kharisma yang berlokasi di Kampung Mokwam SP-5 Prafi menggunakan mesin penyaring tipe saringan berayun yang dirakit sendiri oleh pemiliknya. Tipe saringan ayun untuk ekstraksi pati singkong juga banyak digunakan oleh Industri kecil di Thailand (Yimmengkol, 2009) dan di India (Maanickavasagan dan Thangavel, 2006).

Darma et al., (2010; 2017; 2019) mengembangkan mesin ekstraksi pati tipe stirrer rotary blade dan berfungsi dengan baik untuk mengekstraksi pati sagu, bahkan telah digunakan oleh para petani sagu di beberapa sentra penghasil sagu di Papua Barat.Mesin ekstraksi ini telah dilakukan uji pendahuluan untuk untuk mengekstraksi pati singkong dan berfungsi dengan baik. Namun kinerja mesin ekstraksi tipe stirrer rotary blade ini untuk mengekstraksi pati singkong belum diketahui. Tujuan penelitian ini adalah uji kinerja mesin ekstraksi pati tipe stirrer rotary blade untuk mengektraksi pati singkong. 


\section{METODOLOGI}

\section{Lokasi dan Waktu Penelitian}

Pengujian kinerja mesin dilaksanakan di tempat pengujian mesin ekstraksi pati, berlokasi di samping gedung Fakultas Teknologi Pertanian Universitas Papua, Manokwari. Bahan baku untuk pengujian yaitu umbi singkong segar dibeli di Kampung Mokwam, Distrik Masni, Kabupaten Manokwari, Papua Barat.

\section{Bahan dan Alat Penelitian}

Bahan-bahan yang digunakan ialah umbi singkong segar, air bersih, bahan bakar bensin dan oli mesin (SAE 20-50W). Peralatan yang digunakan yaitumesin ekstraksi pati tipe stirrer rotary blade(Darmaet al., 2020), mesin pemarut singkong tipe silinder bertenaga motor bakar (Sangaji, 2019), pompa air mitsumoto 1,5 inch, timbangan duduk digital kapasitas $150 \mathrm{~kg}$, stop watch, terpal, ember, baskom, saringan manual 100 mesh, parang, pisau dapur, kunci pipa dan kunci pasberbagai ukuran untuk pemasangan mesin di tempat pengolahan.

\section{Deskripsi Mesin Ekstraksi Pati yang Digunakan}

Mesin ekstraksi pati yang digunakan adalah tipe stirrerrotary blade bertenaga motor bakar bensin (Darma et al., 2014; 2017; 2020) yangdiproduksi oleh bengkel permesinan Agroindustri Fakultas Teknologi Pertanian Universitas Papua. Prinsip kerja dari mesin ini menggabungkan proses pengadukan (stirring), peremasan (zqueezing) dan penyaringan (screening/sieving) secara simultan dalam suatu tabung ekstraksi. Ke tiga proses tersebut dengan bantuan air mengakibatkan pati terpisah dari ampas untuk kemudian dialirkan ke bak pengendapan pati. Penggabungan ke tiga proses tersebut secara simultan dalam satu ruang/tempat (tabung ekstraksi) memungkinkan dibuat konstruksi mesin yang lebih sederhana sehingga harganya lebih murah dibandingkan dengan tipe saringan berayun dan tipe saringan berputar.

Komponen-komponen utama mesin ini adalah: (1) tabung ekstraksi,terbuat daribahan plat baja anti karat SS 304 tebal $2 \mathrm{~mm}$ berbentuk tabung berdiameter $76 \mathrm{~cm}$, tinggi $120 \mathrm{~cm}$ dan pada dasar silinder dibuat berbentuk kerucut (conical) yang bertujuan untuk mencegah terjadinya endapan pati di dasar tabung, (2)saringan, dari bahan anti karat (stainless steel SS 304) 100 mesh,(3)sirip/bladestasioner, terbuat dari baja strip anti karat SS 304 berukuran $4 \mathrm{~cm} \times 0,5$ $\mathrm{cm} \times 100 \mathrm{~cm}$, terdiri dari 24bilah (blades) yang dipasang secara vertikal pada dinding tabung bagian dalam, (4) pengaduk/stirrer, dari bahan SS 304 yang terdiri dari 4 bilahvertikal dan 26 bilah horisontal,(5)rangka utama, dari bahan besi siku ukuran $5 \mathrm{~cm} \times 5 \mathrm{~cm} \times 0,5 \mathrm{~cm}$ (SNI), (6)motor penggerak, berupa motor bakar honda 4 tak 6,5 hp, (7) pipa penyalur suspensi pati, menggunakan pipa PVC 2 inch yang dilengkapi dengan stop kran pada ujung pengeluaran. Peralatan pendukung yang merupakan bagian tak terpisahkan dari mesin ini adalah pompa air, bak pengendapan patidan bak penampungan air. Pada Gambar 1 dan Tabel 1 berturut-turut ditampilkan konstruksi dan spesifikasi teknis dari mesin ekstraksi pati tipe stirrer rotary blade yang digunakan pada penelitian ini. 

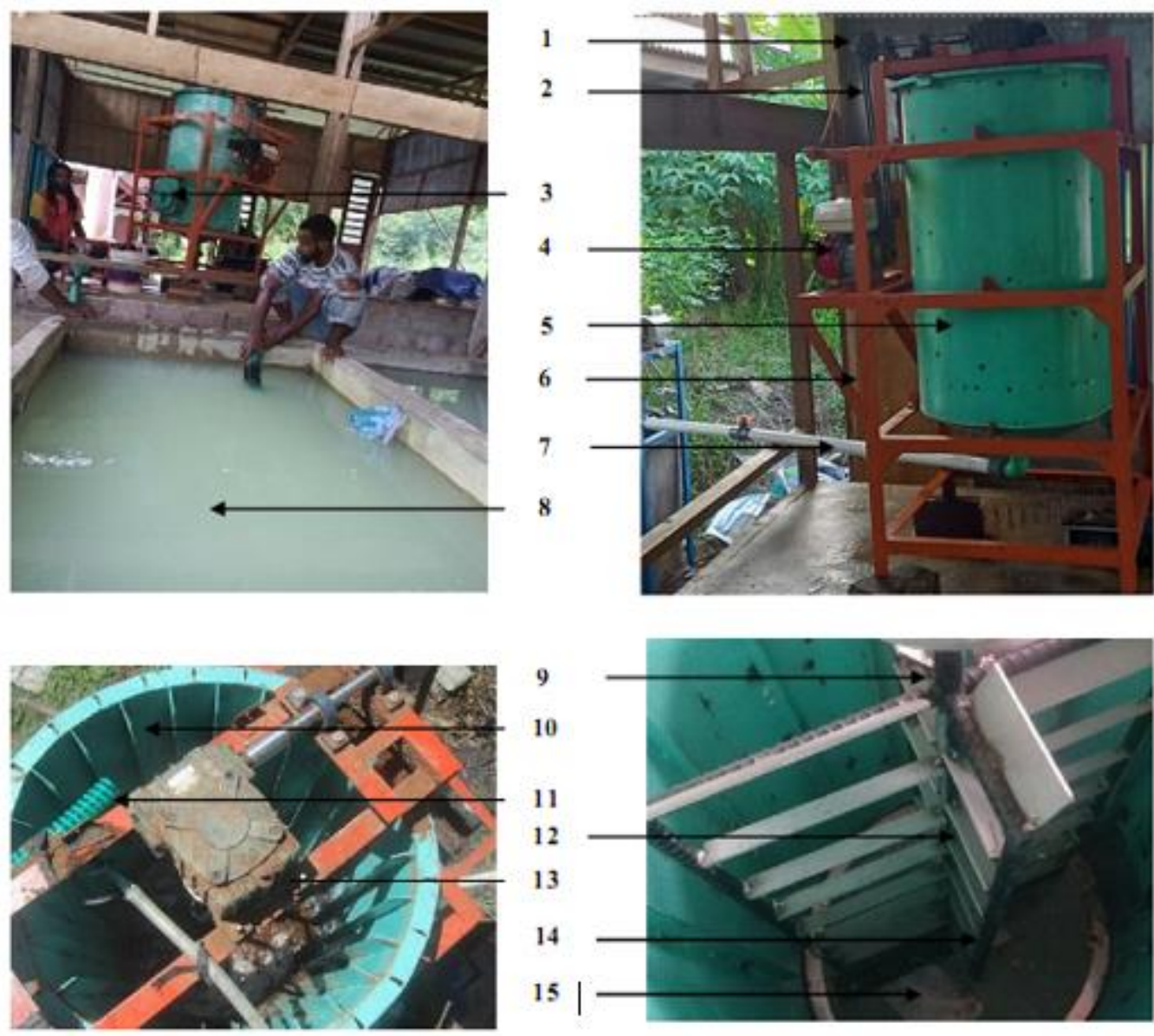

(1) pulley gear box, (2) v-belt, (3) pintu pengeluaran ampas, (4) motor penggerak, (5) tabung ekstraksi

(6) rangka utama (7) pipa penyalur suspensi pati (8) bak pengendapan, (9) porosstirrer,(10) bilah stasioner, (11) selang pemasukan air, (12) bilah horizontal, (13) reduction gear box, (14) bilah vertikal, (15) saringan 100 mesh

Gambar 1. Konstruksi mesin ekstraksi pati sagu tipe verticalstirrer rotary blades

Tabel 1. Data teknis mesin ekstraksi pati tipe stirrer rotary blade bertenaga motor bakar bensin (Darma et al., 2020)

\begin{tabular}{|l|l|l|}
\hline No & Nama & Mesin ekstraksi pati tipe STB \\
\hline 1. & Dimensi (P x L x T ) & $118 \mathrm{~cm} \mathrm{x} 90 \mathrm{~cm} \mathrm{x} 170 \mathrm{~cm}$ \\
\hline 2. & Dimensi Tabung $\varnothing \times \mathrm{T})$ & $76 \mathrm{~cm} \times 120 \mathrm{~cm}\left(\right.$ volume: $\left.0,54 \mathrm{~m}^{3}\right)$ \\
\hline 3. & Material Tabung & Stainless steel SS 304 \\
\hline 4. & Sistim Ekstraksi & Pengadukan dan Penyaringan \\
\hline 5. & Transmisi & V - Belt A-83 $(2$ buah) \\
\hline 6. & Putaran Pengaduk & $100 \mathrm{rpm}$ \\
\hline 7. & Screen Apertures & $100 \mathrm{mesh}$ \\
\hline 8. & Motor Penggerak & Honda GX 200, 6.5 HP \\
\hline
\end{tabular}

\section{Prosedur Pengujian Kinerja Mesin dan Analisis Data}

Bagan alir prosedur pengujian kinerja mesin ditampilkan pada Gambar 2. Pengujian dilakukan 3 kali ulangan dengan mengekstrakpati dari hancuran umbi singkong.
Evaluasi kinerja mesin dilakukan dengan mengukur variabel (1) kapasitas ekstraksi, (2) rendemen pati basah, (3) rendemen pati kering dan (4) kehilangan pati pada ampas (starch losses). Data yang diperoleh dianalisis secara 


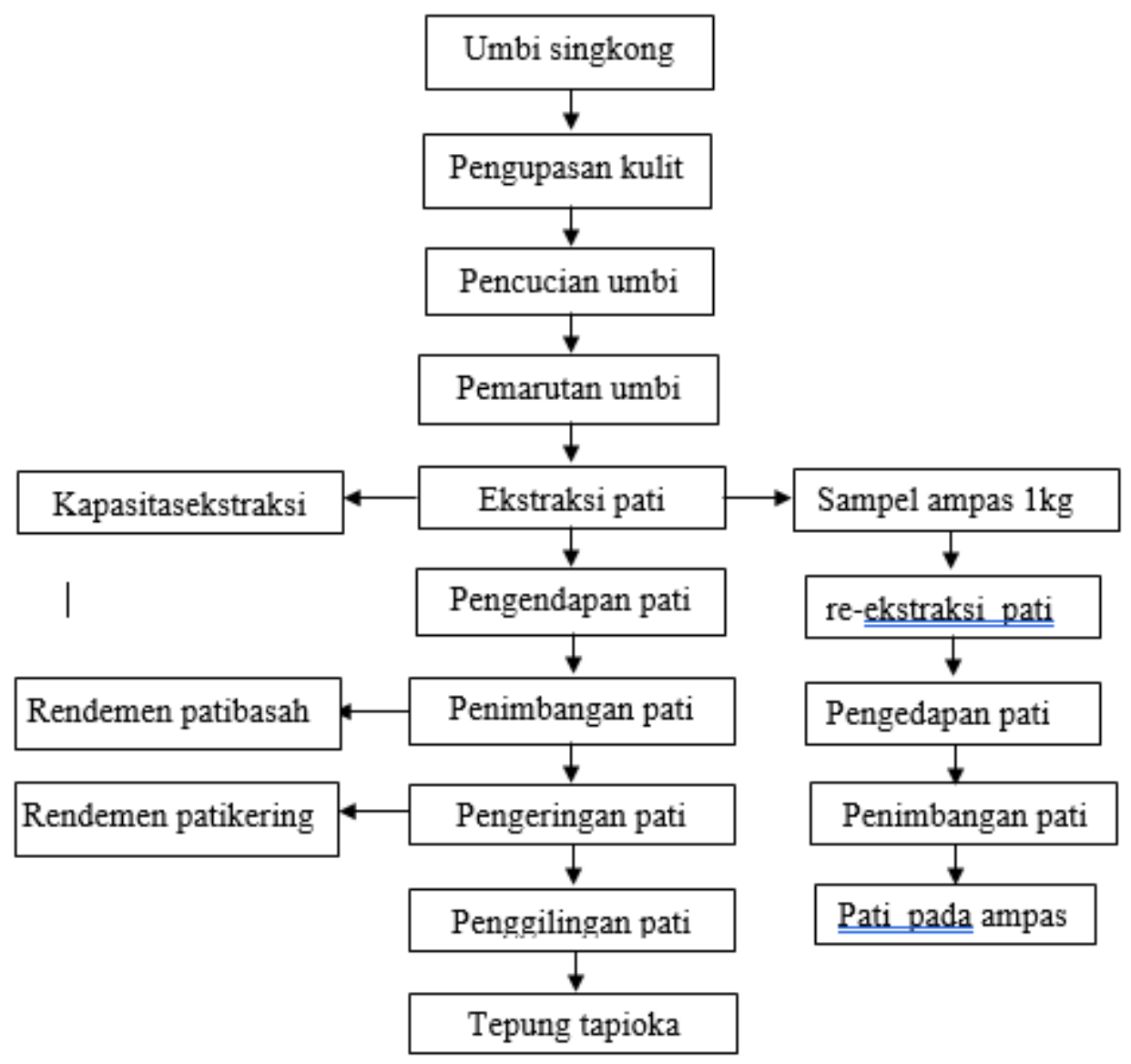

Gambar 2. Bagan alir proses pengujian kinerja mesin ekstraksi tipe stirrer rotary blade untuk ekstraksi pati singkong

Kapasitas ekstraksi

Kapasitas ekstraksi dihitung dengan menggunakan persamaan (1) :

$$
K E=\frac{m u(k g)}{t(j a m)}
$$

Keterangan :KE adalah kapasitas ekstraksi (kg/jam), mu adalah massa umbi hasil parutan yang diekstraksi $(\mathrm{kg})$ dan $t$ adalah waktu ekstraksi (jam).

\section{Rendemen pati basah}

Rendemen pati basah dihitung menggunakan persamaan (2):

$$
R D=\frac{m p(k g)}{m u(k g)} x 100 \%
$$

Keterangan $: R D$ adalah rendemen pati basah (\%), mpadalah massa pati basah/pati segar $(\mathrm{kg})$ dan $m u$ adalah massa umbi hasil parutan $(\mathrm{kg})$.

\section{Rendemen pati kering}

Pati basah hasil ekstraksi dijemur menggunakan sinar mata hari hingga kadar air $12 \%$. Rendemen pati kering dihitung dengan menggunakan persamaan (3):

$$
R D K=\frac{m p k(k g)}{m u(k g)} x 100 \%
$$

Keterangan :RDK adalah rendemen pati kering (\%), mpkadalah massa pati kering (kg) dan $m u$ adalah massa umbi hasil parutan $(\mathrm{kg})$.

\section{Kehilangan pati pada ampas}

Kehilangan pati (starch losses) pada ampas dihitung menggunakan persamaan (4):

$$
P A=\frac{m p a(k g)}{m a(k g)} \times 100 \%
$$

Keterangan $: P A$ adalah kehilangan pati pada ampas (\%), mpa adalah massa pati pada ampas (kg) danma adalah massa ampas $(\mathrm{kg})$ 


\section{HASIL DAN PEMBAHASAN}

\section{Kapasitas Ekstraksi}

Sebelum dilakukan proses ekstraksi pati, terlebih dahulu kulit umbi dikupaskemudian dicuci lalu dihancurkan menggunakan mesin parut singkong (Gambar 3). Umbi hasil parutan kemudian ditimbang masing-masing $95 \mathrm{~kg}$ untuk setiap ulangan (Gambar 4).Pemarutan bertujuan untuk menghancurkan dinding sel sehingga granula pati yang terdapat dalam sel-sel jaringan umbi menjadi terbebebas (freed starch) sehingga tersuspensi ke dalam air pada saat ekstraksi. Tanpa merusak dinding sel jaringan umbi, pati tidak bisa dipisahkan pada saat proses ekstraksi karena masih terkurung dalam sel-sel (unfreed state). Hasil pengukuran kapasitas ekstraksi pada 3 kali ulangan disajikan pada Tabel 2.
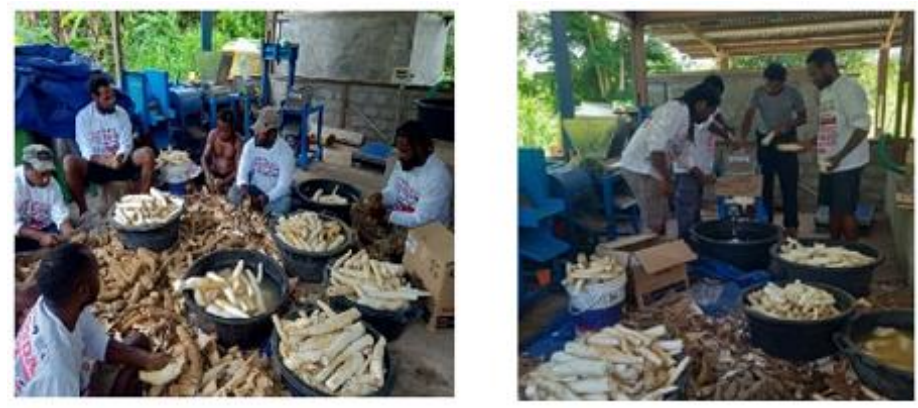

Gambar 3. Pengupasan kulit (kiri) dan pemarutan umbi singkong (kanan)
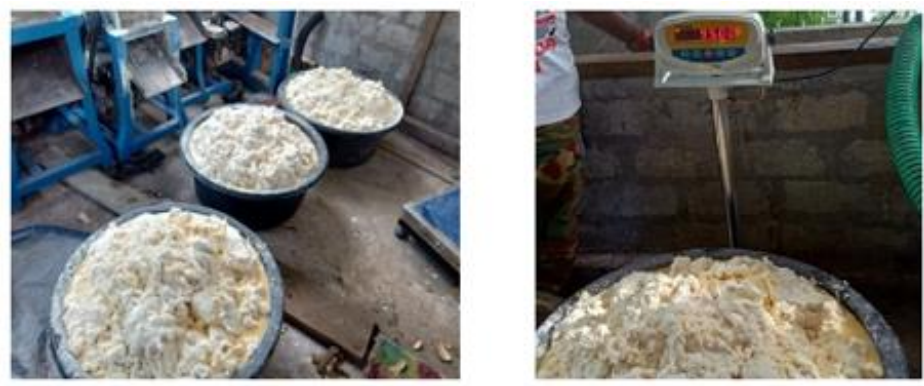

Gambar 4. Umbi hasil parutan (kiri) dan penimbangan parutan umbi (kanan)

Tabel 2. Kapasitas ekstraksi pada berbagi ulangan

\begin{tabular}{lcccccc}
\hline Ulangan & $\begin{array}{c}\text { Massa } \\
\text { umbi } \\
\text { parut (kg) }\end{array}$ & $\begin{array}{c}\text { Waktu } \\
\text { input } \\
\text { bahan } \\
\text { (menit) }\end{array}$ & $\begin{array}{c}\text { Waktu } \\
\text { ekstraksi } \\
\text { (menit) }\end{array}$ & $\begin{array}{c}\text { Waktu } \\
\text { kelurkan } \\
\text { ampas } \\
\text { (menit) }\end{array}$ & $\begin{array}{c}\text { Total } \\
\text { waktu } \\
\text { (menit) }\end{array}$ & $\begin{array}{c}\text { Kapasitas } \\
\text { ekstraksi } \\
\text { (kg/jam) }\end{array}$ \\
\hline 1 & 95 & 1,38 & 19,44 & 4,12 & 24,94 & 228,9 \\
2 & 95 & 2,20 & 20,07 & 4,28 & 26,55 & 214,6 \\
3 & 95 & 1,54 & 20,64 & 4,04 & 26,22 & 217,3 \\
\hline Rata-rata & 95 & 1,71 & 20,05 & 4,15 & 25,90 & 220,3 \\
\hline SD & 0 & 0,43 & 0,60 & 0,12 & 0,85 & 7,60 \\
\hline
\end{tabular}

Berbeda dengan mesin ekstraksi tipe saringan berayun (shaking/oscillating screen) maupun tipe saringan berputar (rotating screen) yang menggunakan sistem kontinu, mesin ekstraksi tipe stirrer rotary blade menggunakan sistem batch (tidak kontinu) dalam pengoperasiannya. Waktu yang diperlukan untuk sekali batch/proses terdiri dari (1) input bahan ke dalam tabung ekstraksi,

(2) proses ekstraksi, melibatkan proses pengadukan (stirring), peremasan (squeshing) dan penyaringan (screening), dan (3) pengeluaran ampas (bagas) dari dalam tabung.

Berdasarkan Tabel 2 terlihat bahwa kapasitas ekstraksi rata-rata adalah 220,3 $\mathrm{kg} / \mathrm{jam}$, dengan rata-rata waktu yang diperlukan untuk sekali proses adalah 25,90 menit $(0,43$ jam $)$. Waktu yang diperlukan untuk sekali proses (batch) ekstraksi terdiri dari input atau masukan bahan ke dalam 
tabung ekstraksi (1,71 menit), ekstraksi (20,05 menit) dan pengeluaran ampas (4,15 menit). Total waktu yang diperlukan untuk sekali proses rata-rata 25,9 menit $(0,43$ jam $)$.

Proses ekstraksi diawali dengan memasukkan air terlebih dahulu sekitar $40 \%$ dari volume tabung kemudian motor penggerak (engine) dihidupkan dan bahan dimasukkan ke dalam tabung ekstraksi. Selama proses ekstraksi berlangsung ditambahkan air secara konstinu menggunakan pompa air. Jumalah aliran air yang dimasukan kedalam tabung ekstraksi sama dengan jumlah aliran suspensi pati ke bak pengendapan pati. Jumlah aliran keluar dari dalam tabung dikontrol dengan stop kran yang dipasang pada pipa penyalur pati. Jika jumalah aliran air yang dimasukan lebih banyak dari jumlah air yang keluar maka bubur pati (slurry)akan tumpah melalui permukaan tabung. Sebaliknya kalau air yang masuk lebih sedikit maka bubur pati dalam tabung menjadi lebih kental sehingga menurunkan efektivitas proses ekstraksi. Proses ekstraksi dihentikan pada saat aliran suspensi dari dalam tabung sudah jernih yang mengindikasikan bahwa pati terbebas (freed starch) telah terekstrak semua.

Kapasitas ekstraksi rata-rata mesin ini sebagaimana disajikan pada Tabel 3 yaitu $220,3 \mathrm{~kg}$ singkong parut/jam. Hasil ini konsisten dengan kapasitas mesin tersebut saat digunakan untuk mengekstraksi pati sagu. Hasil penelitian Darma et al., (2017); Boyratan (2020) dan Solissa (2019) memperoleh kapasitas ekstraksi ela sagu berturut-turut antara 171 - $222 \mathrm{~kg}$ ela/jam, 150 - $200 \mathrm{~kg} / \mathrm{jam}$ dan $161-252 \mathrm{~kg}$ ela/jam. Hasil penelitian Saunggay (2019) dan Darma et al., (2020) juga menggunakan mesin ekstraksi yang sejenis untuk ekstraksi pati sagu, menghasilkankapasitas ekstraksi rata-rata berturut-turut adalah $243,8 \mathrm{~kg}$ ela/jam $240 \mathrm{~kg}$ ela/jam.

\section{Rendemen Pati Basah dan Pati Kering}

Setelah pengendapan pati selama 4 jam, air supernatant dibuang dari bak pengendapan (dewatering) dan pati hasil ekstraksi dikumpulkan dan ditimbang (Gambar 5) untuk perhitungan rendemen pati basah menggunakan persamaan (2). Pati basah selanjutnya dijemur menggunakan sinar matahari (Gambar 6) hingga kadar air $12 \%$. Pati kering kemudian digiling menggunakan disc mill dan ditimbang massanya untuk memperoleh rendemen pati kering menggunakan persamaan (3). Hasil perhitungan rendemen pati basah dan rendemen pati kering disajikan pada Tabel 3.
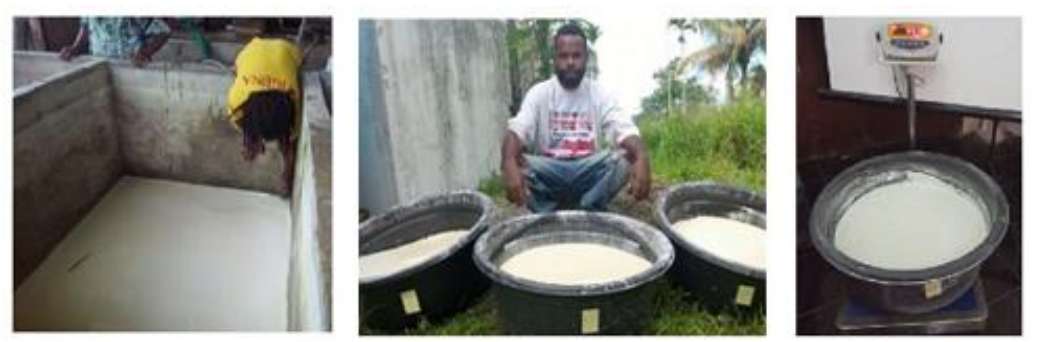

Gambar 5. Endapan pati dalam bak pengendapan (kiri) dan penimbangan pati (kanan)
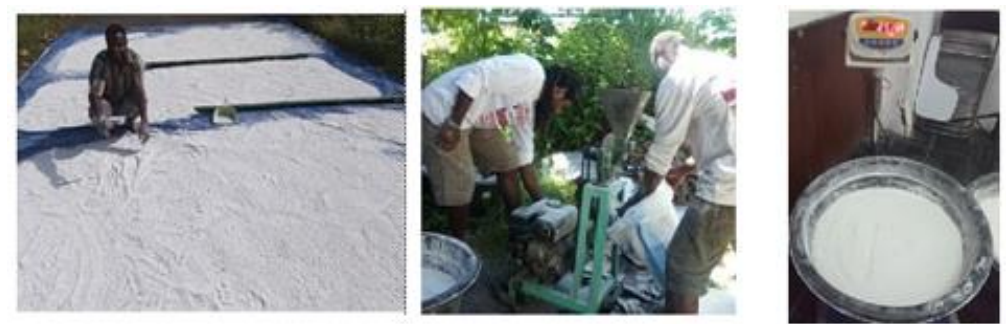

Gambar 6. Pengeringan pati (kiri), penggilingan pati (tengah) dan penimbangan pati kering (kanan) 
Tabel 3. Rendemen pati basah dan rendemen pati kering rata-rata pada 3 kali ulangan.

\begin{tabular}{cccccc}
\hline Ulangan & $\begin{array}{c}\text { Massa umbi } \\
\text { parut (kg) }\end{array}$ & $\begin{array}{c}\text { Massa pati } \\
\text { basah (kg) }\end{array}$ & $\begin{array}{c}\text { Rendemen } \\
\text { pati basah } \\
(\%)\end{array}$ & $\begin{array}{c}\text { Massa pati } \\
\text { kering (kg) }\end{array}$ & $\begin{array}{c}\text { Rendemen pati } \\
\text { kering }(\%)\end{array}$ \\
\hline 1 & 95 & 44,15 & 46,47 & 27,15 & 28,58 \\
2 & 95 & 44,20 & 46,53 & 27,10 & 28,53 \\
3 & 95 & 44,10 & 46,42 & 28,05 & 29,53 \\
\hline Rata-rata & 95 & 44,15 & 46,47 & 27,43 & 28,88 \\
\hline SD & & 0,05 & 0,06 & 0,53 & 0,56 \\
\hline
\end{tabular}

Pada Tabel 3 terlihat bahwa rata-rata rendemen pati basah adalah $46,47 \%$. Hasil ini konsisten dengan hasil penelitian Aman et al., (2019) dan Sangaji (2019) dengan menggunakan metode ekstraksi secara manual memperoleh rendemen pati basah berturut-turut $45,66 \%$ $46,67 \%$ dan $43,36 \%$. Hasil penelitian ini juga sejalan dengan hasil penelitian Irwansyah (2019) dan Wayangkau (2020) yang memperoleh rendemen pati basah berturutturut $38-48 \%$ dan 49,2\%. Hasil pengolahan pati singkong oleh Industri pengolahan tapioka IKM Kharisma di SP 5 Manokwari menghasilkan rendemen pati basah 39,62\% (Cliver, 2020). Hasil penelitian Sajev et al., (2012) dan Mustafa (2015) menghasilkan rendemen pati basah berturut-turut 37,96\% dan $29,55 \%$. Rendemen pati selain dipengaruhi oleh efektivitas mesin dan teknik pengolahan, juga dipengaruhi jenis dan umur panen yang optimal dari bahan yang digunakan (Tita et al., 2012).
Rendemen pati kering rata-rata 28,88\% (Tabel 3). Hasil penelitian Sajev et al., (2012) memperoleh rendemen pati kering 18,98\%. Rendemen pati kering dari berbagai industri pengolahan skala kecil di Vietnam bagian utara bervariasi antara 25-27\% (Guillaume et al., 2008).Di Industri pengolahan tapioca IKM Kharisma di SP 5 Manokwari menghasilkan rendemen pati kering 23,91\% (Cliver, 2020). Hasil penelitian Mustafa (2015) menghasilkan rendemen pati kering 18,74\%.

Kehilangan Pati Pada Ampas (starch losses)

Setelah proses ekstraksi selesai untuk setiap ulangan (batch), sebanyak $1 \mathrm{~kg}$ sampel ampas diekstraksi lagi secara manual hingga air perasan jernih (Gambar 7). Pati yang diperoleh dari ekstraksi pati pada ampas ini dikumpulkan dan ditimbang massanya untuk menentukan persentase kehilangan pati pada ampas (tidak terekstrak pada saat proses ekstraksi).Semakin tinggi persentase pati pada ampas berarti semakin besar kerugian akibat kehilangan (losses) pati terikut bersama ampas.

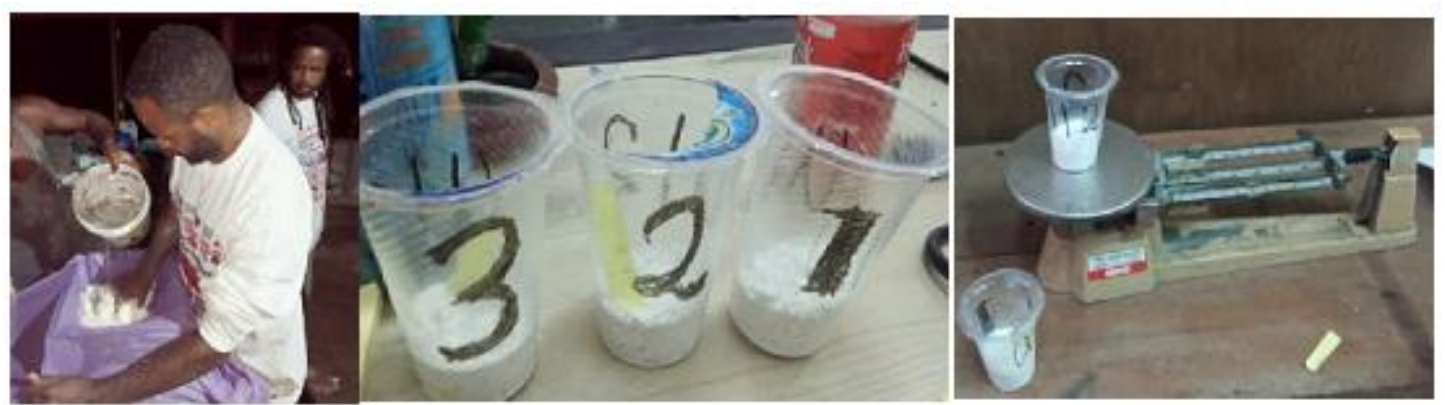

Gambar 7. Ekstraksi pati pada ampas (kiri), pati yang dihasilkan dari sampel ampas (tengah) dan penimbangan pati (kanan)

Kehilangan pati pada ampas merupakan salah satu variabel penting dalam menilai kinerja mesin ekstraksi. Hasil pengukuran kehilangan pati pada ampas ditampilkan pada Tabel 4. 
Tabel 4. Kehilangan pati pada ampas

\begin{tabular}{cccc}
\hline Ulangan & $\begin{array}{c}\text { Massa sampel } \\
\text { ampas }(\mathrm{kg})\end{array}$ & $\begin{array}{c}\text { Massa pati pada ampas } \\
(\mathrm{kg})\end{array}$ & $\begin{array}{c}\text { Persentase pati pada } \\
\text { ampas }(\%)\end{array}$ \\
\hline 1 & 1 & 0,030 & 3,0 \\
2 & 1 & 0,023 & 2,3 \\
3 & 1 & 0,024 & 2,4 \\
\hline Rata & 1 & 0,026 & 2,6 \\
\hline SD & & 0,004 & 0,379 \\
\hline
\end{tabular}

Berdasarkan Tabel 4 memperlihatkan bahwa persentase kehilangan pati pada ampas rata-rata 2,6\%. Pati yang dapat terekstrak (starch recovery) pada proses ekstraksi hanyalah butiran pati yang telah terbebas (freed starch) sebagai akibat dari telah rusaknya sel jaringan umbi pada saat proses pemarutan. Jadi pati yang diperoleh dari hasil re-ekstraksi ampas adalah pati yang telah dalam keadaan terbebas (freed starch) namun belum terekatrak pada saat proses ekstraksi. Sedangkan sebagian pati yang masih dalam keadaan tidak terbebas (unfreed starch) tetap terikut bersama ampas.

Persentase pati yang belum terbebas selama proses pemarutan bervariasi tergantung derajat kehalusan hancuran umbi parut. Sulit untuk memperoleh keseluruhan kandungan pati hanya pada satu kali pemarutan, oleh karena itu di industri-industri besardilakukan pemarutan tahap-2 (second rasping procces) setelah ekstraksi. Diperkirakan efisiensi pemarutan tahap-1 sekitar $85 \%$ (Rajakumari, 2010).Pada pemarutan tahap-2, gigi parut harus lebih kecil agar dihasilkan hasil parutan yang lebih halus. Selain pemarutan tahap-2 untuk memperoleh pati yang belum terbebas, penghancuran ampas dapat juga dilakukan menggunakan hammer mill. Untuk skala laboratorium, penghancuran ampas dapat menggunakan blender. Hasil penelitian Aman et al., (2019), Irwansyah (2019) dan Darma et al., (2020) memperoleh pati pada ampas setelah diblender berturut-turut 10,7 - 14\%, 17,17 - 22,53\%dan 7,61 - 16,17\%. Wayangkau (2020) juga menggunakan blender untuk menghancurkan ampas singkong dan memperoleh pati pada ampas rata-rata 5,6\%.

\section{KESIMPULAN}

Mesin ekstraksi pati tipe stirrer rotary bladebertenaga motor bakar bensin berfungsi baik (work properly) dengan kinerja tinggi untuk mengekstraksi pati singkong. Kinerja mesin adalah (1) kapasitas ekstraksi 220,3 kg umbi parut/jam, (2) rendemen pati basah $46,47 \%$, (3) rendemen pati kering $28,88 \%$ dan (d) kehilangan pati pada ampas $2,6 \%$.

\section{DAFTAR PUSTAKA}

Aman, W.P., Darma, Roreng, M. K. dan Sardi, (2019), Rancangan dan Kinerja Teknis Mesin Parut Singkng Tipe Silinder Bertenaga Motor Bakar, Jurnal Rekayasa: Journal of Science and Technology, 12 (1), pp. 59-65.

Boiratan, C., (2020), Modifikasi Komponen Saringan dan Pengaduk Serta Uji Kinerja Mesin Ekstraksi Pati Sagu Tipe Vertikal Stirrer Rotary Blade, Skripsi, Universitas Papua, Manokwari.

Badan Pusat Statistik Provinsi Papua Barat, 2018. Provinsi Papua Barat dalam Angka 2018, Manokwari.

Cliver, F.,(2020), Analisis Neraca Massa Industri Tapioka pada Industri Kecil Menengah Kharisma di Distrik Masni, Kabupaten Manokwari, Skripsi, Fakutas Tekongi Pertanian, Universitas Papua, Manokwari.

Darma, Istalaksana, P. dan Gani, A. (2010), Prototype Alat Pengekstrak Pati Sagu Tipe Mixer Rotary Blade Bertenaga Motor Bakar, Jurnal Agritech, 30 (4), pp. 204-211.

Darma dan Santoso, B., (2017), Variant-3 Mesin Ekstraksi Pati Sagu Tipe Stirrer Rotary Blade Bertenaga Motor Bakar Bensin, Prosiding Seminar Nasional: Mewujudkan Kedaulatan Pangan Melalui Penerapan Inovasi Teknologi Pertanian Spesifik Lokasi pada Kawasan Pertanian,Sorong, Papua Barat, 9 November, 2017, pp. 440-451.

Darma, (2018), Improvement of Sago Processing Machiney, in Ehara, H., Toyoda, Y. and Johnson, D.V. (Eds.). SAGO PALM: Multiple Contribution to 
Food Security and Sustainable Livelyhoods, Springer. Singapore, pp. 231-246.

Darma, Faisol, A. dan Sangaji, A., (2020), Rancang Bangun dan Uji Kinerja Mesin Pemarut Singkong Tipe Silinder untuk Produksi Tepung Tapioka, Jurnal Rekayasa: Journal of Science and Technology, 13 (3), pp. 254-262.

FAO,(2018),Food Outlook - Biannual Report on Global Food Markets - November 2018, Rome.

Guillaume D., Dufor, D.C., Marouse, Tanh, M.L. and Marechal, P.A.,(2008). Cassava Starch Processing at Small Scale in North Vietnam, Starch Journal, 60 (2008). pp.358-372.

Irwansyah, E. 2019.Pengembangan Prototype dan Uji Kinerja Mesin Pemarut Singkong (Manihot utilissima Phol) Bertenaga Motor Bakar dengan Sistem Pengumpanan Bahan Throw in. Skripsi, Fakutas Tekongi Pertanian Universitas Papua, Manokwari.

Kementerian Ketenagakerjaan Republik Indonesia, (2016) Lampiran Keputusan Menteri Ketenagakerjaan Republik Indonesi No. 104 Tentang Penetapan Standar Kompetensi Kerja Nasional Indonesia Kategori Industri Pengolahan Golongan Pokok Industri Makanan Bidang Pengolahan Tapioka, Menteri Ketenagakerjaan RI, Jakarta.

Maanickavasagan, A. and Thangavel, K., (2006). A Survey of Water Consumption and Product output from Ten Sago Factories in India, Journal Trop. Agric. Sci, 29 (1), pp.67-72.

Mustafa, A.,(2015),Analisis Proses Pembuatan Pati Ubi kayu (tapioka) Berbasis Neraca Massa. Jurnal Agrointek, 9(2), pp. 127133.
Rajakumari, D., (2010), A Study on Sago Industries in Salem District, Tamil Nandu, Thesis Doctor of Philosophy, Bharahtidasan University, Tiruhcirappalli, Tamilnandu, India.

Sajeev, M.S., Nanda, S.K. and Sheriff, J.T., (2012). An Efficient Blade Type Rasper for Cassava Starch Extraction.Journal of Root Crops, 38 (2), pp.151-156.

Sangaji, D.A., (2019), Desain dan Uji Kinerja Mesin Pemarut Singkong (Manihot utilissima Phol) Bertenaga Motor Bakar untuk Ekstraksi Pati, Skripsi, Fakultas Teknologi Pertanian, Universitas Papua, Manokwari.

Saunggay, R., (2019), Studi Pengolahan Sagu (Metroxylon Sp) Secara Mekanis kampung arbefondi Distrik Supiori Selatan Kabupaten Supiori Provinsi Papua, skripsi, Universitas Papua, Manokwari.

Solissa, A. T., (2019), Pengembangan Prototipe dan Uji Kinerja Mesin Ekstraksi Pati Sagu Tipe Vertikal Stirrer Rotary Blade Bertenaga Motor Bakar Bensin, skripsi, Universitas Papua, Manokwari.

Wayangkau, R., (2020), Modifikasi dan Uji Kinerja Mesin Pemarut Singkong (Manihot utilissimaPhol) Bertenaga Motor Listrik, Skripsi, Fakultas Teknologi Pertanian, Universitas Papua, Manokwari.

Yimmongkol, S.,(2009), Research and Development Projects on Improvement of the Potential Use of Dried Cassava Pulp and Cassava Leaf Meal in Concentrate of Feedlot Cattle, Thesis Doctor of Philosophy, Agricultural Research and Development Graduate School, Kasetsart University. 